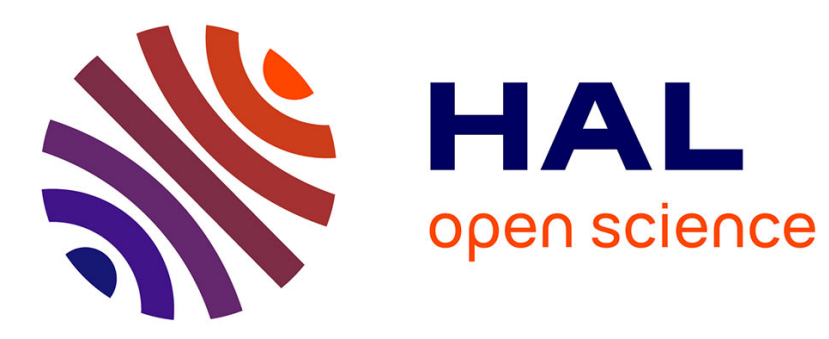

\title{
Platform-Based Business Ecosystems - A Framework for Description and Analysis
}

\author{
Christoph H Wecht, Mike Demuth, Frank Koppenhagen
}

\section{To cite this version:}

Christoph H Wecht, Mike Demuth, Frank Koppenhagen. Platform-Based Business Ecosystems - A Framework for Description and Analysis. 22nd Working Conference on Virtual Enterprises (PRO-VE 2021), Nov 2021, Saint-Etienne, France. pp.92-100, 10.1007/978-3-030-85969-5_8 . emse-03327428

\section{HAL Id: emse-03327428 \\ https://hal-emse.ccsd.cnrs.fr/emse-03327428}

Submitted on 24 Nov 2021

HAL is a multi-disciplinary open access archive for the deposit and dissemination of scientific research documents, whether they are published or not. The documents may come from teaching and research institutions in France or abroad, or from public or private research centers.
L'archive ouverte pluridisciplinaire $\mathbf{H A L}$, est destinée au dépôt et à la diffusion de documents scientifiques de niveau recherche, publiés ou non, émanant des établissements d'enseignement et de recherche français ou étrangers, des laboratoires publics ou privés. 


\title{
Platform-Based Business Ecosystems - A Framework for Description and Analysis
}

\author{
Christoph H. Wecht ${ }^{1}$, Mike Demuth ${ }^{2}$, Frank Koppenhagen ${ }^{3}$ \\ ${ }^{1}$ New Design University, Mariazeller Strasse 97a, \\ 3100 St. Pölten, Austria \\ christoph.wecht@ndu.ac.at \\ ${ }^{2}$ University of St.Gallen, Dufourstrasse 50, \\ 9100 St. Gallen, Switzerland \\ mike.demuth@student.unisg.ch \\ ${ }^{3}$ Hamburg University of Applied Sciences, Berliner Tor 21, \\ 20099 Hamburg, Germany \\ frank.koppenhagen@haw-hamburg.de
}

\begin{abstract}
Value creation is increasingly driven by digital or semi-digital business models. Platforms offer the necessary backbone for such highly profitable business models. Our research centers on the questions how platforms are created, which drivers are behind this development and how platforms are successfully implemented. We analyzed various business ecosystems and their underlying platforms to understand the various roles companies can take in platform-based business ecosystems. Based on our results we propose a framework to describe business ecosystems as well as a canvas to analyze their underlying platforms, the acting companies' roles, and the applied business models. One case study illustrates this tool. Our results will (1) help to understand why companies bet on platforms to establish business ecosystems, (2) analyze the processes and methods behind successful business ecosystems, and (3) reflect about the dominant and still growing importance of platform-based business ecosystems.
\end{abstract}

Keywords: Business ecosystem, platform, multi-sided platform, platform-based business ecosystem, ecosystem framework, business model, innovation, twosided market

\section{Introduction}

Value creation is increasingly driven by digital or semi-digital business models utilizing network effects. Namely platforms have received increasing interest from scholars in management research, particularly in general management [e.g. 1, 2], organizational studies [e.g. 3, 4] and innovation management [e.g. 5, 6]. Besides, the topic also became subject to multiple publications of practitioner-oriented periodicals [e.g. 7, 8] underlining the importance of platforms in management practice. However, even though the body on platform literature is growing rapidly many aspects are still in 
need for better specification. One of these aspects is the understanding how platform business models in combination with an innovation ecosystem work and get innovated $[6,9,10]$. Multi-sided platforms have ecosystems where participants are organized in lose networks [11] and innovation from outside a company gets attracted based on technological interfaces and modularization [12]. This innovation activities occur in two different forms, as complementary co-innovation, whereby the focal firm can complement its offering, or in form of an open innovation approach [13]. This is also reflected in their respective business models, which describe interdependent activities of the focal firm and partners [14]. Moreover, the environment of platforms and their ecosystems is usually very volatile due to the fast technological progress and the constant change of market conditions in platform economies [15].

\section{Platforms, Ecosystems, and Business Models}

So far, platform business models have been explained in a mainly economic-driven context of two-sided market platforms [e.g. 16, 17] and in terms of antecedents for a successful platform business model [e.g. 18]. Nevertheless, research did not emphasize how platforms, business ecosystems, and business models are linked. Hence, we address this gap in our research in order to (a) strengthen the promising link between business model and platform research and to (b) gain a better insight how the roles of companies in platform-based ecosystems influence their business models.

In theory, despite a growing number of research especially on multi-sided platforms [e.g. 19, 20, 13], the platform concept still lacks of a deeper theoretical foundation [cf. 21]. By combining the platform literature with the business model (innovation) stream, we deliver new insights on the phenomenon and subsequently contribute to its rootedness in the management literature.

\subsection{Platforms}

Building on the former, mainly engineering driven publications on platforms [e.g. 22], a new platform notion emerged focusing on rather business-driven platform types, which allow agents to connect and exchange in an efficient way and even create completely new markets [e.g. 23, 24]. These platforms are built in a modular fashion with a stable technical core and periphery components, which can be innovated by independent, external developers $[12,6,1]$. Each platform has a platform leader, platform users, and independent innovators. These entities form the platform ecosystem $[11,25]$.

\subsection{Business Ecosystems}

Ecosystem as a management theory was originally introduced by Moore [26] stating that the key success factor for generating sustainable, competitive advantages is to outinnovate the existing industry competition. Using the analogy of a biological ecosystem, the notion business ecosystem is presented as a collaborative network of 
companies that co-evolve around innovation [26]. Despite the increasing significance of ecosystems in the business practice, the term has been used with no unanimous definition or sound theoretical backing [27]. For the sake of this analysis Teece's ecosystem definition is used: "Organizations, institutions, and individuals that impact the fate of the focal firm and its customers and suppliers, including complementors, suppliers, regulatory authorities, standard setting bodies, the judiciary, and educational and research institutions" [28]. In a platform ecosystem, the platform leader takes a special role as important governance functions are performed by this company [cf. 29]. Hence, decisions on the technological core and interfaces as well as the platform business model have to be elaborated well.

\subsection{Business Models}

Our research centers on the questions how platforms are linked to business models, which drivers are behind the ecosystem development and how platform-based ecosystems are successfully implemented. The business model literature aims to answer the question how companies create value. Despite the fast growing body of literature, there is still a very vivid debate on the theoretical foundation and the conceptualization of business models [e.g. 14]. Zott, Amit and Massa [30] argue that no theory fully describes the value creation through business models, while different domains of the topic developed independently, resulting in various concepts and definitions. Nevertheless, a basic agreement amongst researches was achieved as the elements value creation, value delivery and value capturing are widely regarded as describing parts of a business model [31, 32]. The business models need to be correspondingly and continuously innovated in order to maintain competitive advantages.

\section{Platform-Based Ecosystem Framework}

We analyzed various business ecosystems and their underlying platforms to understand the underlying business models and differentiate the various roles companies can take in those ecosystems. Platform-based ecosystems are based on the mechanism of network effects $[33,34]$. Strong network effects are an important value driver for platforms as they might create "winner-take-all" situations amongst competing platforms [35, 21]. Another stream of research identifies the key strengths of managerial ecosystems as the potential to create synergy caused by complementary relationships. Jacobides, Cennamo and Gawer [36] argue that ecosystems create nongeneric complementary relationships both on the production as well as on the consumer side and that there is no need of vertical integration. The emphasis on complementarities of ecosystems leads to this description: "An ecosystem is a set of actors with varying degrees of multilateral, non-generic complementarities that are not fully hierarchically controlled" [36]. Even though the authors still anticipate that an ecosystem consists of one orchestrator and multiple participants, the power and control 
within an ecosystem is not centralized by the orchestrator. Participants within an ecosystem keep residual control over the services or products they offer to the customers via the ecosystem.

\subsection{Roles in the Framework}

A company that wants to enter ecosystems has several strategic positioning opportunities as described in the following part leading to our proposed framework. Based on our results we propose a framework to describe and analyze business ecosystems, their underlying platforms and the applied business models. The ecosystem in the narrower sense consists of the platform leader, its partner(s), the users/customers, and its complementors. Adding politics/law, technology, competitors and culture leads to the ecosystem in a wider sense (figure 1). The core ecosystem is therefore led by the platform leader, the focal firm in the ecosystem, the orchestrating party [cf. 20]. According to Adner [37], the key responsibility of an orchestrator is to determine the value proposition of the ecosystem, to select suitable members and to secure the position among other ecosystems in the future.

A platform leader can be supported by an ecosystem partner, who is responsible for the ecosystem as well. The role of the partner is to support the platform leader, which can be technological support like the provision of the platform, or strategic support such as being the main shareholder. The orchestrator relies on complementors in the ecosystem to deliver their contribution to the strategically defined product or service. Complementors are bound together through an interdependency, e.g. by adhering to certain regulation or governance principles. [36]

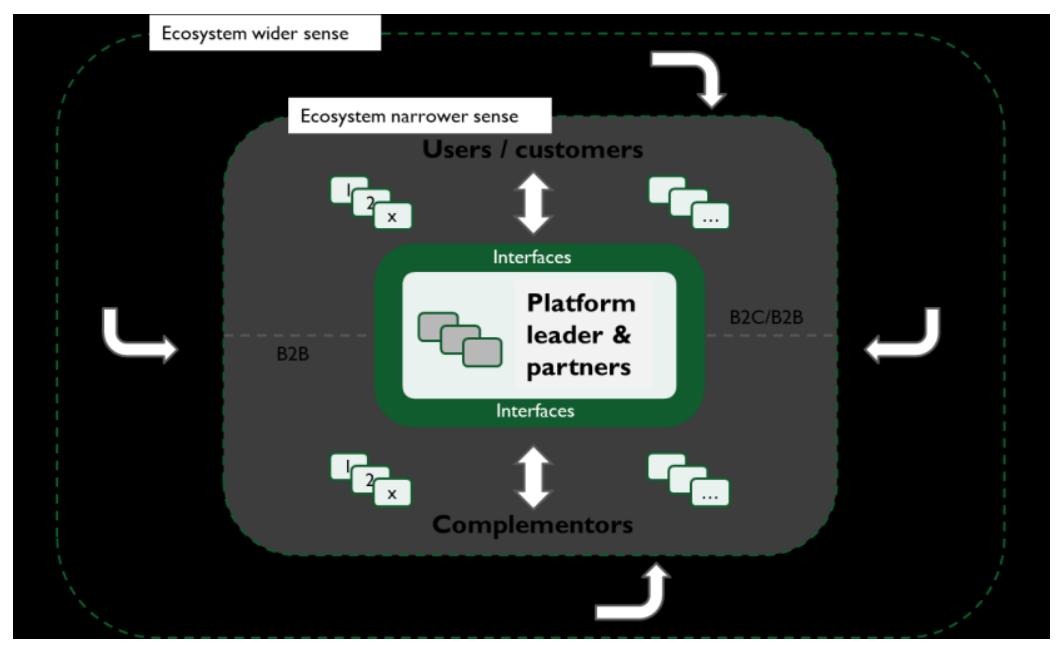

Fig. 1. The Platform-based Ecosystem Framework (own illustration)

In order to realize the focal value proposition, product and service offerings are contributed by the ecosystem complementors [26]. As mentioned by Teece [28] the idea is using the core competencies of the complementors to enhance the overall value 
proposition of an ecosystem. This requires a complementary relationship between the platform leader and the complementor itself. The last actor within an ecosystem is the user or customer. Ecosystems are designed from a customer-centric perspective, and the core idea is to create a product or service system that responds to a fundamental need of the customer [36].

\subsection{Linking Ecosystem Framework and Business Models}

According to Täuscher and Laudien, there is a need to understand holistically how platform business models work and how their possible manifestations and approaches can look like [38]. Business models can be described by answering four questions: (1) Who is the target customer? (2) What is offered to the customer? (3) How is the value proposition created? (4) Why does the business model generate profit? [39]. This approach is combined with the Platform-based Ecosystem Framework to derive at the canvas depicted in figure 2. This Platform-based Ecosystem Business Model Canvas is used to evaluate and understand such platform business models by examining value streams between the platform actors and analyzing their interrelationships. This helps to understand how the actors interpret their role and benefit from the ecosystem.

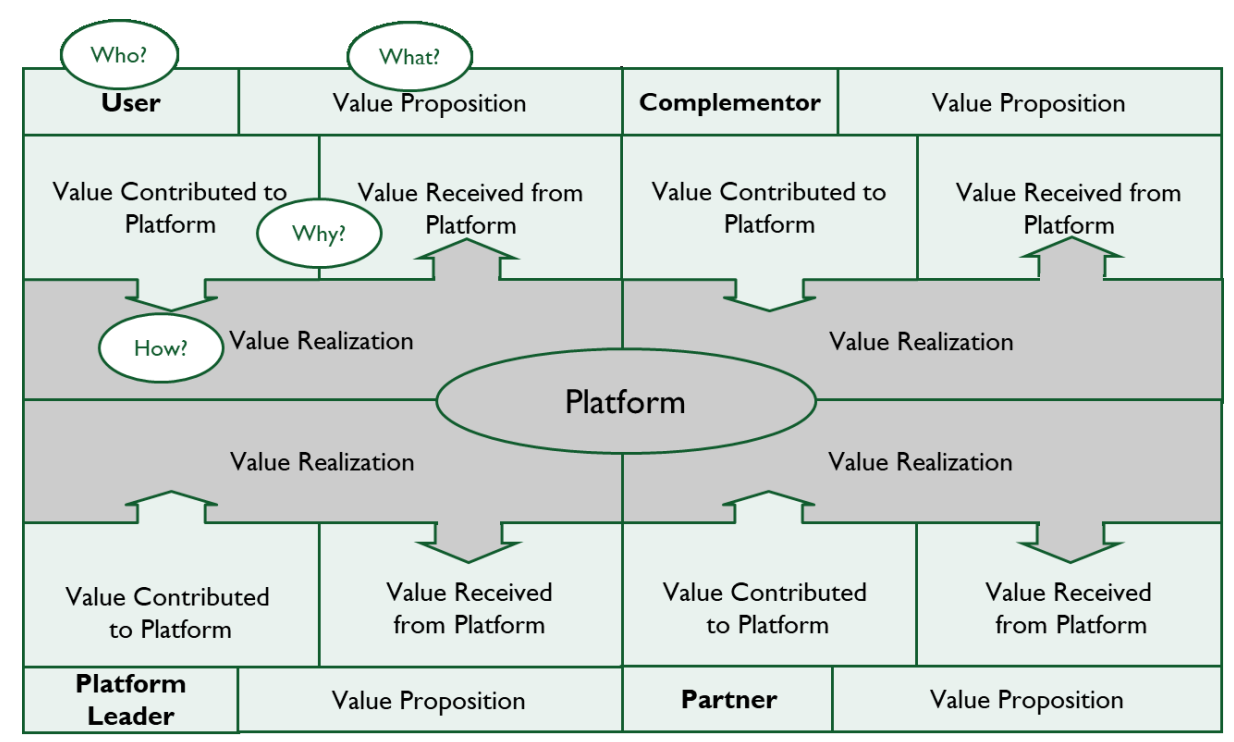

Fig. 2. The Platform-based Ecosystem Business Model Canvas (own illustration)

The coordination of the ecosystem is possible on the basis of the rules and regulations set [40]. Ecosystem rules can be strictly defined, especially in the case of technologybased platforms, but can also be just a set of unexpressed expectations. The rules and standards can govern various aspects, such as entry to the ecosystem, participation level 
and behavior [36]. According to Pauli et al. [41] a platform firm's success depends on their "ability to leverage an ecosystem of actors who contribute to the platform in various ways".

\section{Case Study MoneyPark}

We applied this canvas to more than 20 ecosystems in the $\mathrm{DACH}$ region over the last five years. MoneyPark is an example for a developing business ecosystem in the Swiss real estate market. In 2012, MoneyPark created a platform for mortgage comparisons thereby increasing product choice and price comparability for customers at the same time. In combination with desk research, interviews with four different ecosystem actors were conducted, analyzed and compared, namely the platform provider MoneyPark, the partner Helvetia and the two complementors Mobiliar and Credit Suisse. Our case study focusses on certain aspects of this mortgage "sub ecosystem" as shown in figure 3. Over time, the initial platform evolved in a network with more than 150 complementors. The mortgage broker business centered on Mobiliar and Credit Suisse as key complementors is still the core of MoneyPark's ecosystem. Financing as first area of activities enabled the expansion towards additional services with added value for the customers. In order to capture network effects that push the rapid growth of the platform-based ecosystem they focused initially on the actions and mechanisms that drive value creation to reach the critical network mass. Following the platformbased ecosystem idea MoneyPark set-up win-win situations with its partners and complementors. Once this step was reached, the platform started to focus on securing parts of the value creation for itself. [cf. 42]

Findings suggest that Money Park's customer-centric approach tackles major customer pain points along the journey of a real estate purchase, such as the low price comparability and the high time expenditure around mortgages. In addition, ecosystem complementors are able to gain customer access and thereby gather customer data without facing initial acquisition costs. 


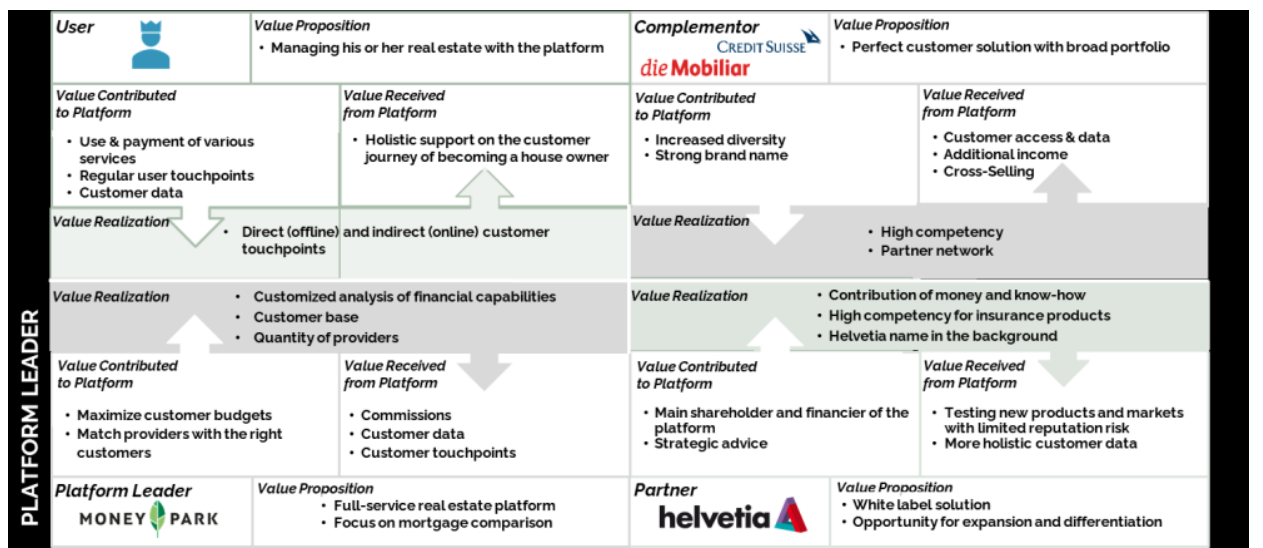

Fig. 3. Sector of the MoneyPark ecosystem (own illustration)

The platform-based ecosystem around MoneyPark is based upon multilateral value creation in collaborative networks. The constellation of users, platform leader, partner and complementors results in distinct value streams within the ecosystem. While matching insurance companies with insurance-seeking customers might be viewed as a rather transactional value creation by the platform provider (reduction of acquisition costs for complementors and creation of price advantages for users), other contributions have a more profound value potential. Provided by the ecosystem users themselves, the customer data represents such a component whose underlying value goes beyond the scope of a single business. While the platform provider MoneyPark uses a customer's property information to create additional digital services that involve building projects in the surrounding neighborhood, the complementor Mobiliar plans to make use of the same customer data by creating tailored marketing initiatives in combination with its subsidiaries. Therefore, the ecosystem MoneyPark fits into Moore's notion of business ecosystems as it co-creates potential for further innovations, like the forming of additional services that extend the scope or intensify the depth of the user journey as it is addressed today.

According to Adner [37], every member has to set up its own strategy and secure its own role in a competitive ecosystem. Therefore, the use or non-use of the underlying value potentials discussed above can be partly attributed to the individual strategies of the ecosystem actors. Especially for ecosystem complementors, the sole capturing of additional revenue streams appears to constitute a sufficient motive to participate in the ecosystem MoneyPark. Being satisfied with their role, the complementors positively influence the overall product variety for ecosystem users. With every new complementor in the ecosystem there is an increasing likelihood that customers find a provider meeting their requirements in terms of quality, location, or price, thus creating positive network effects. 


\section{Conclusion and Paths for Future Research}

Platform-based business ecosystems play an important role in offering a complete, well-integrated set of solutions that can cross a variety of industries and help to address pressing customer problems. This development is possible due to different companies cooperatively working together in order to co-evolve capabilities around new innovations and create new value together. By analyzing the ecosystems and business models of selected companies we were able to derive implications regarding the structure of ecosystems built upon their underlying platforms.

As every research, our article is subject to limitations. In particular, we derived most of our data from secondary sources, which only allowed us to analyze the topic on a high level not providing further insights into the exact decision making process of managers selecting their roles in the platform-based ecosystem and choosing their respective business model.

However, the combination of business model innovation and platform-based business models promises some fruitful paths for future research. While this paper addresses how platform-based ecosystems require different roles and business models future research could investigate how connections between different business models of an ecosystem are established and what patterns they follow. Additionally, it could be of interest how managers identify threats and chances for their platforms, for instance by applying the attention-based view on this research topic.

Our results will help to understand why companies bet on platform-based business models to establish business ecosystems, analyze the processes and methods behind successful business ecosystems, and reflect about the dominant and still growing importance of collaborative network aspects in today's business world.

Acknowledgments. We thank Madeleine Horgby, Laura Raschle, Léonie Leser, and Samuel Schweizer for their contribution to this study.

\section{References}

1. Thomas, L., Autio, E., \& Gann, D.: Architectural leverage: putting platforms in context. Academy of Management Perspectives, 3015(1), 47-67 (2015)

2. Zhu, F., \& Iansiti, M.: Entry into platform-based markets. Strategic Management Journal, 106(May), 88-106 (2012)

3. Boudreau, K. J.: Let a thousand flowers bloom? An early look at large numbers of software app developers and patterns of innovation. Organization Science, 23(3), 1409-1427 (2012)

4. Gawer, A., \& Phillips, N.: Institutional Work as Logics Shift: The Case of Intel's Transformation to Platform Leader. Organization Studies, 34(8), 1035-1071(2013)

5. Frattini, F., Bianchi, M., De Massis, A., \& Sikimic, U.: The Role of Early Adopters in the Diffusion of New Products: Differences between Platform and Nonplatform Innovations. Journal of Product Innovation Management, 31(3), 466-488 (2014)

6. Gawer, A., Cusumano, M. A.: Industry Platforms and Ecosystem Innovation. In: J Prod Innov Manag 31 (3), S. 417-433 (2014) 
7. Accenture. Technology Vision 2015. Retrieved December 21st, 2015 from https://www.accenture.com/us-en/_acnmedia/Accenture/ConversionAssets/Microsites/Documents11/Accenture-Technology-Vision-2015.pdf (2015)

8. Deloitte. Business ecosystems come of age. Retrieved from https://www2.deloitte.com/content/dam/insights/us/articles/platform-strategy-new-levelbusiness-trends/DUP_1048-Business-ecosystems-come-of-age_MASTER_FINAL.pdf (2015)

9. Tucci, C. L., Chesbrough, H., Piller, F., West, J., \& Fe, E. P.: When do firms undertake open, collaborative activities? Introduction to the special section on open innovation and open business models. Industrial and Corporate Change, 25(2), 283-288 (2016)

10.Vanhaverbeke, W., Chesbrough, H., \& West, J. (Eds.). Surfing the New Wave of Open Innovation Research. In New Frontiers in Open Innovation pp. 281-294. Oxford University Press (2014)

11.Adner, R., \& Kapoor, R.: Innovation ecosystems and the pace of substitution: Re-examining technology S-curves. Strategic Management Journal (2015)

12.Chesbrough, H. W., \& Van Alstyne, M.: Permissionless innovation. Communications of the ACM, 58(8), 24-26 (2015)

13.Mancha, R. \& Gordon, S. Multi-sided platform strategies for organizations: transforming the business model. Journal of Business Strategy (2021)

14.Amit, R., \& Zott, C.: Crafting Business Architecture: the Antecedents of Business Model Design. Strategic Entrepreneurship Journal, 9(4), 331-350 (2015)

15.Nambisan, S., \& Baron, R. A.: Entrepreneurship in Innovation Ecosystems: Entrepreneurs' Self-Regulatory Processes and Their Implications for New Venture Success. Entrepreneurship Theory and Practice, 37(5), 1071-1097 (2013)

16.Brousseau, E., \& Penard, T.: The Economics of Digital Business Models: A Framework for Analyzing the Economics of Platforms. Review of Network Economics, 6(2), 81-114 (2007)

17.Hagiu, A., \& Wright, J.: Multi-sided platforms. International Journal of Industrial Organization, 43, 162-174 (2015)

18.Chesbrough, H. W.: Open Innovation: Where We've Been and Where We're Going. Research-Technology Management, 55(4), 20-27 (2012)

19.Bivona, E. \& Cosenz, F. Designing a Multi-Sided Platform business model assessment framework: a Dynamic Performance Management perspective. Systems Research and Behavioral Science, 38(1), 93-107 (2019)

20.Hou, H. \& Shi, Y. Ecosystem-as-structure and ecosystem-as-coevolution: A constructive examination. Technovation, 100, 102193 (2021)

21.Gawer, A., \& Cusumano, M. A.: Industry Platforms and Ecosystem Innovation. Journal of Product Innovation Management, 31(3), 417-433 (2014)

22.Baldwin, C. Y., \& Clark, K.: Managing in an age of modularity. Harvard Business Review, 75(5), 84-93 (1997)

23.Armstrong, M.: Competition in two-sided markets. The RAND Journal of Economics, 37(3), 668-691 (2006)

24.Hagiu, A., \& Spulber, D.: First-party content and coordination in two-sided markets. Management Science, 59(4), 933-949 (2013)

25.Mäkinen, S. J., Kanniainen, J., \& Peltola, I.: Investigating Adoption of Free Beta Applications in a Platform-Based Business Ecosystem. Journal of Product Innovation Management, 31(3), 451-465 (2014)

26.Moore, J. F.: Predators and prey: a new ecology of competition. Harvard Business Review, 71(3), 75-86 (1993)

27.Tsujimoto, M., Kajikawa, Y., Tomita, J., \& Matsumoto, Y. A review of the ecosystem concept - Towards coherent ecosystem design. Technological Forecasting and Social Change, 136, 49-58 (2018) 
28.Teece, D. J.: Explicating dynamic capabilities: the nature and microfoundations of (sustainable) enterprise performance. Strategic Management Journal, 28(13), 1319-1350 (2007)

29.Scholten, S., \& Scholten, U.: Platform-based Innovation Management: Directing External Innovational Efforts in Platform Ecosystems. Journal of the Knowledge Economy, 3(2), 164$184(2012)$

30.Zott, C., Amit, R., \& Massa, L.: The Business Model: Recent Developments and Future Research. Journal of Management, 37(4), 1019-1042 (2011)

31.Casadesus-Masanell, R., \& Ricart, J. E.: From Strategy to Business Models and onto Tactics. Long Range Planning, 43(2-3), 195-215 (2010)

32.Winterhalter, S., Zeschky, M. B., \& Gassmann, O.: Managing dual business models in emerging markets: an ambidexterity perspective. R\&D Management, 46(3) 464-479 (2016)

33.Cusumano, M. A.: The evolution of platform thinking. Communications of the ACM 53 (1): 33-35 (2010)

34.Parker, G. G., \& Van Alstyne, M.: Two-sided network effects: A theory of information product design. Management Science, 51(10), 1494-1504 (2005)

35.Eisenmann, T., Parker, G. G., \& Van Alstyne, M.: Strategies for two-sided markets. Harvard Business Review, 84(10), 91-101 (2006)

36.Jacobides, M. G., Cennamo, C., \& Gawer, A.: Towards a theory of ecosystems. Strategic Management Journal, 39(8), 2255-2276 (2018)

37.Adner, R.: Ecosystem as Structure. Journal of Management, 43 (1), 39-58 (2017)

38.Täuscher, K., \& Laudien, S. M. Understanding platform business models: A mixed study of marketplaces. European Management Journal, 36(3), 319-329 (2018)

39. Gassmann, O., Frankenberger, K., \& Csik, M.: The Business Model Navigator: 55 Models That Will Revolutionise Your Business. Pearson (2014)

40.Pidun, U., Reeves, M., \& Schüssler, M. (2019, September 27). BCG. Do You Need a Business $\begin{array}{lllll}\text { Ecosystem? } & \text { Retrieved } & \text { November } & 520 & \text { from }\end{array}$ https://www.bcg.com/publications/2019/doyou-need-business-ecosystem

41.Pauli, T., Marx, E., Dunzer, S., \& Matzner, M. Modeling Platform Ecosystems. In CEUR Workshop Proceedings (Vol. 2716) (2020)

42.Jacobides, M. G., Sundararajan, A., \& Van Alstyne, M. Platforms and Ecosystems: Enabling the Digital Economy. Briefing Paper World Economic Forum, (pp. 1-32). Cologny/Geneva (2019) 